\title{
An investigation of the nuclei of hülle cells of Aspergillus nidulans
}

\author{
Marcos D.F. Carvalho ${ }^{1,2}$, Marta S. Baracho ${ }^{1}$ and Ivanhoé R. Baracho ${ }^{1}$ \\ ${ }^{1}$ Departamento de Genética e Evolução, Universidade de Campinas, SP, Brazil. \\ ${ }^{2}$ Departamento de Zootecnia, Centro de Ciências Agrárias, Universidade Federal do Piauí, Pi, Brazil.
}

\begin{abstract}
Certain species of fungi of the genus Aspergillus produce a type of cells around the cleistothecium that are called hülle cells. To facilitate the analysis of the formation of these cells, an Aspergillus nidulans strain with high hülle cell production was obtained. Hülle cells from this strain were allowed to grow on dialysis membranes, where it was possible to observe their nuclei. The material was fixed with Carnoy, hydrolyzed with $\mathrm{HCl}$ and stained with Giemsa. Several nuclei approximately equal in size to the nuclei of hyphae and conidia were observed during the phase of hülle cell formation. The formation of a macronucleus measuring approximately $3.1 \mu \mathrm{m}$ was observed in mature hülle cells. To compare the DNA amount, hülle cells and conidia of the $\mathrm{CH}-89$ strain were isolated and submitted to DNA extraction (Tuyl, 1977). The amount of DNA per cell was, on average, 17.2 times greater than the amount of DNA in the conidia.
\end{abstract}

Key words: Aspergillus nidulans, hülle cell, macronuclei in fungi, nuclei of A. nidulans, macronuclei in hülle cell.

Received: April 8, 2002; accepted: October 4, 2002.

\section{Introduction}

Hülle cells are characteristic structures normally produced by some species of the genus Aspergillus. These cells are associated with the cleistothecia of all ascogenous species of the Aspergillus nidulans group, abundantly occurring around it. Globose and subglobose hülle cells also appear in certain species of the Aspergillus versicolor group. Cells with the same characteristics but quite different in size and shape are encountered in both the Aspergillus ustus and the Aspergillus flavipes groups (Raper and Fennell, 1965). The association of hülle cells with the cleistothecia that normally occur in certain groups of the Aspergilli suggests the participation of these cells in the formation of cleistothecia (Eidam, 1883; Herman, Kurtz and Champ, 1983; Zonneveld, 1988).

Although Aspergillus nidulans has been an amenable species for genetic studies, and several aspects of $A$. nidulans has been investigated, since the pioneer work by Pontecorvo et al. (1953), little is known about the cytology of hülle cells that occur in this species (Doby and Kombila-Favry, 1978). Ellis, Reynolds and Alexopoulos (1973), using transmission microscopy, noted the existence of various nuclei in these cells, but the cell function has remained obscure.

Send correspondence to Marta Baracho, Departamento Genética e Evolução, Universidade de Campinas, Caixa Postal 6109, 13081-970 Campinas, SP, Brazil. E-mail: martbaracho@ hotmail. com.
The objective of the present investigation was to observe the nuclei of the hülle cells of a special strain of Aspergillus nidulans at different stages of cellular development. Schwartz (1928) showed that these cells may germinate, acting as reproductive cells. Thus the investigation of their nuclei can be of great value to clarify aspects of their formation and development.

\section{Materials and Methods}

Media

Minimal medium (MM) was Czapek-Dox with 1\% $(\mathrm{w} / \mathrm{v})$ glucose. Complete medium (CM) contained yeast extract, hydrolyzed casein, hydrolyzed nucleic acids, vitamins, etc. (Pontecorvo, Roper, Macdonald and Bufton, 1953). Supplemented minimal medium was a mixture of $0.25 \mu \mathrm{g}$ p-aminobenzoic acid, $50 \mu \mathrm{g}$ proline and $20 \mathrm{~mL}$ MM. Solid media contained $2 \%$ agar.

\section{Solutions}

Carnoy fixative was 6:1:1 ethanol, glacial acetic acid and lactic acid. Albumin solution was 5\%(v/v) egg white in distilled water. Giemsa solution was $1.0 \mathrm{~g}$ Giemsa and $54.0 \mathrm{~mL}$ methanol in $84.0 \mathrm{~mL}$ glycerin.

Glycerinated gelatin was prepared by dissolving $5.0 \mathrm{~g}$ gelatin in $30.0 \mathrm{~mL}$ distilled water at 60 to $80^{\circ} \mathrm{C}$ and adding $35.0 \mathrm{~mL}$ glycerin and $0.125 \mathrm{~g}$ phenol with constant shaking. 


\section{Strain}

Strain CH-89, (Department of Genetics and Evolution of UNICAMP) is deficient in proline and p-aminobenzoic synthesis and produces many hülle cells but few cleistothecia. It was obtained by crossing strain A (Nga and Roper, 1968) with strain biA1; meth Gl from the Glasgow stock. Sectors produced, by haploidization of the diploid obtained, were selected for maximum hülle cell production.

\section{Hülle cell staining}

Sterilized dialysis membranes on the surface of solid $\mathrm{CM}$ were inoculated and incubated at $37^{\circ} \mathrm{C}$ for 4 days, then fixed for $25 \mathrm{~min}$. The membranes were then washed in dis- tilled water and hydrolyzed with $1 \mathrm{~N} \mathrm{HCl}$ for 15 min at $25^{\circ} \mathrm{C}$ and for $10 \mathrm{~min}$ at $60^{\circ} \mathrm{C}$. After hydrolysis the material was washed 3 times in distilled water then stained for $1 \mathrm{~h}$ in $10 \mathrm{~mL}$ phosphate buffer $(\mathrm{pH} \mathrm{7)}$ containing 18 drops of Giemsa solution. The stained membranes were mounted in glycerinated gelatin.

To measure the nuclei of mature hülle cells, hyphae were incubated at $37{ }^{\circ} \mathrm{C}$ for 8 days. Hülle cells were harvested, mixed on coverslips with one drop of albumin solution, spread, and then dried for $10 \mathrm{~min}$. The material was fixed and hydrolyzed, as described above, then stained for $20 \mathrm{~min}$. The coverslips were washed and mounted in phosphate buffer. Nuclear diameter of fully developed hülle cells was then measured with an ocular micrometer.

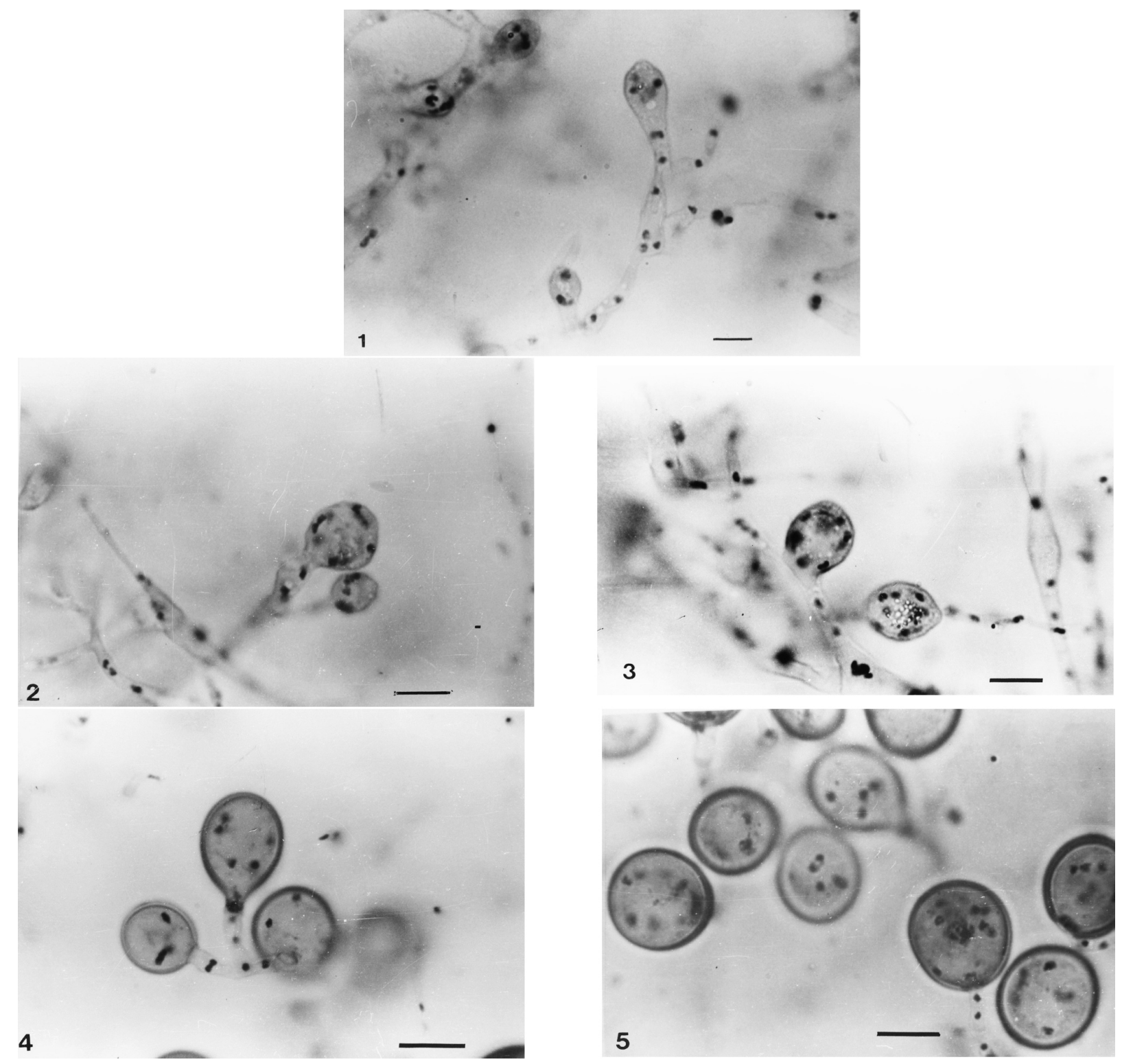

Figures 1-5 - Formation of hülle cells. Figure 1. Initial phase showing the appearance of protuberances at the extremity of hyphae. Bar $=6 \mu \mathrm{m}$. Figures 2-3. Intermediate phase. During this phase the protuberance grows, the wall thickens and the number of nuclei increases. Bars $=6 \mu \mathrm{m}$. Figures 4-5. Intermediate phase, showing mitotic division inside the hülle cells. Bars $=10 \mu \mathrm{m}$. 
To observe nuclei of the germinated cells, hülle cells were incubated for 8 days at $37{ }^{\circ} \mathrm{C}$ on slides with 2 to 3 drops of supplemented minimum medium. The slides were placed on Petri dishes containing moistened filter paper, and sealed with cellulose tape. Slides were removed, 2 drops of albumin solution were added and spread by gravity. The slides were dried for 40 to $60 \mathrm{~min}$, then fixed, hydrolyzed, stained and mounted in glycerinated gelatin.

\section{Conidium staining}

The cytological analysis of the conidia was carried out by the same technique with modifications of staining times. Conidia were mixed on coverslips with one drop of albumin solution, spread, and then dried for $10 \mathrm{~min}$. The material was fixed for $15 \mathrm{~min}$, hydrolyzed for $7 \mathrm{~min}$ at $25^{\circ} \mathrm{C}$ and for $8 \mathrm{~min}$ at $60^{\circ} \mathrm{C}$, washed in water, then stained for $10 \mathrm{~min}$ in diluted Giemsa solution, and mounted in phosphate buffer for measurement of the diameters of nuclei at the microscope.

\section{DNA extraction and quantification}

Hülle cells and conidia were produced as described above. Conidia were transferred to test tubes containing $4 \mathrm{~mL}$ of $0.1 \%(\mathrm{v} / \mathrm{v})$ Tween- 80 solution, disaggregated by shaking and counted with a hemocytometer. Hülle cells were separated by adding about 20 spherical n. 1 glass beads to the Tween suspension, shaking then filtering through a $40 \mu \mathrm{m}$ mesh sieve. The filtrate was then filtered through n 10 filter paper and the retained material was washed 6 times with distilled water. The retained material was resuspended in distilled water, again filtered through n. 10 filter paper, resuspended in distilled water, then centrifuged at 5,000 rpm for $10 \mathrm{~min}$. The precipitates were resuspended in Tween solution and the number of hülle cells counted with a hemocytometer.

Both the conidial suspensions and the hülle cell suspensions prepared as described above were submitted to DNA extraction by the method by Tuyl (1977). After DNA quantification (Gilles and Myers, 1965) in these samples, the amount of DNA per conidium and per hülle cell was estimated.

\section{Results and Discussion}

Using the $\mathrm{CH}-89$ strain and the technique described above, it was possible to accompany the morphological aspects of hülle cells from the initial phase, going through intermediate phases up to the maturation phase. The formation of hülle cells starts with the appearance of a protuberance at the extremity of one hypha, in which nuclei of apparently normal size appear (Figure 1) and the cell wall is fine and transparent. Starting at this point there is a phase that may be called intermediate, during which the protuberance grows, the wall thickens and the number of nuclei increases (Figures 2 and 3), by mitotic division inside the cell
(Figures 4 and 5). Then a structure is formed that seems to result from the grouping of nuclei (Figure 6). This phase is followed by the stage called maturation, during which a single nucleus is observed (Figure 7), several times larger than the nuclei of conidia and hyphae.

These cytological observations thus show that hülle cells of the CH-89 strain are of a multinucleate nature in some stages of formation and that, depending on the stage, there is a variation in the number and size of these nuclei. During the maturation phase the nucleus seems to reach its maximum size, forming what could be called the macronucleus (Figure 8).

The occurrence of macronuclei in A. nidulans is an event that has not yet been described. Although this phenomenon may be more of a curiosity than a practical aid to genetic analysis, it may be, by itself, of great value.

Total understanding of this event is not in sight, since its overall pattern is complex. But, in order to observe the behavior of the macronucleus during the germination process, hülle cells in the maturation phase were left to germinate, then stained and examined under the microscope. The germinating cells showed the presence of a macronucleus and of a normal nucleus that stands close to the germ tube (Figure 9). Although the analysis has been inconclusive, it

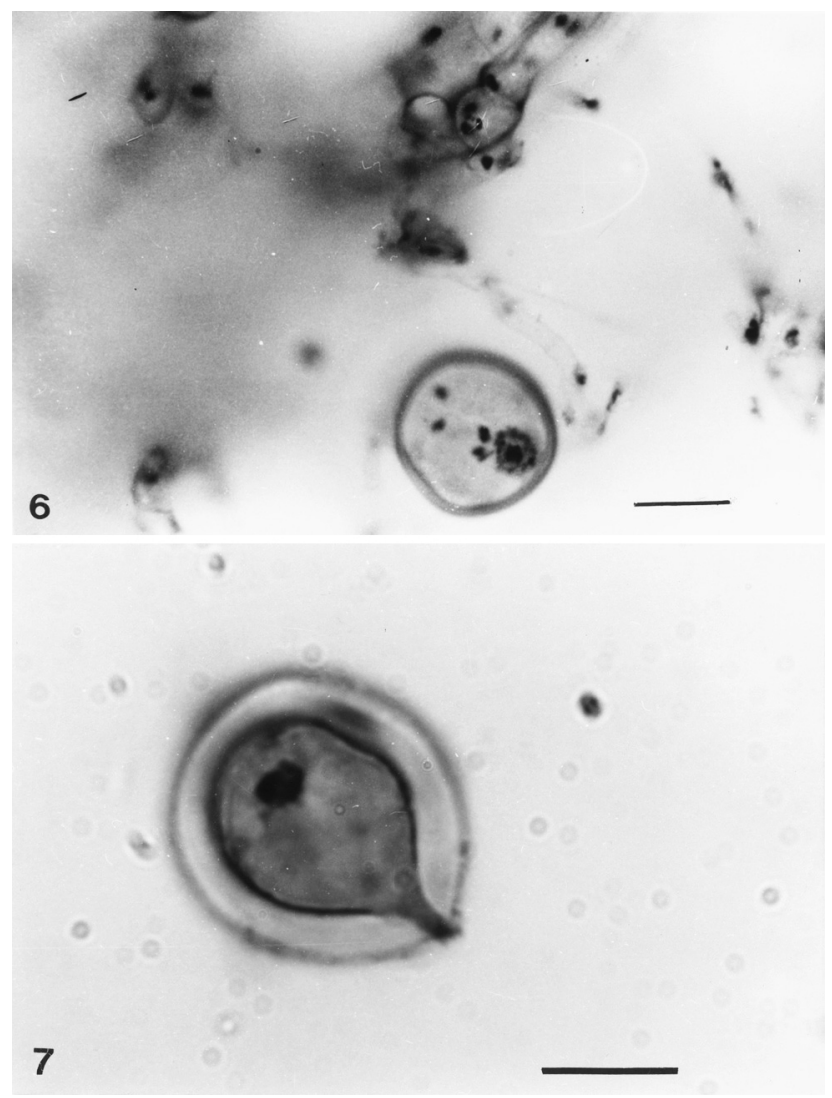

Figures 6-7 - Formation of the macronucleus, and stage of maturation. Figure 6. A structure is formed that seems to result from the grouping of nuclei. Bar $=10 \mu \mathrm{m}$. Figure 7. A single nucleus is observed several times larger than those of conidia and hyphae. Bar $=10 \mu \mathrm{m}$. 


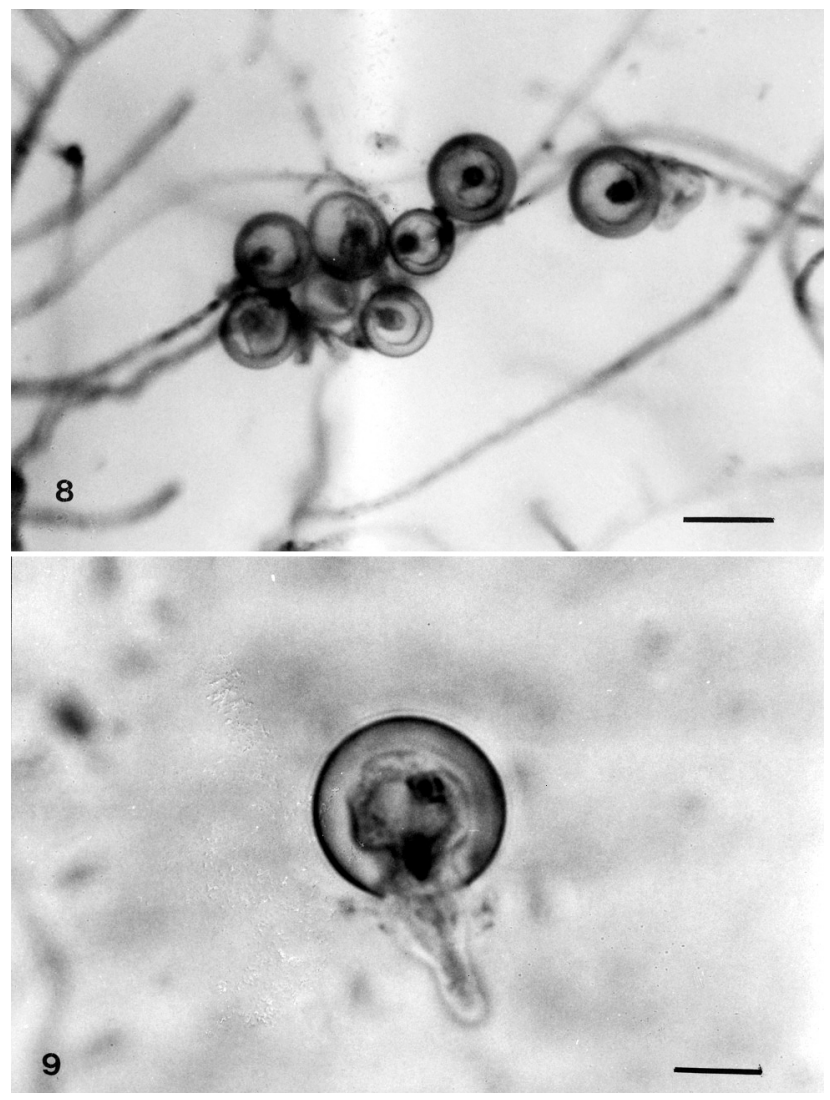

Figure 8-9 - Stage of maturation and germination of hülle cells. Figure 8. Group of hülle cells, showing macronucleus. Bar $=20 \mu \mathrm{m}$. Figure 9. A germinating cell that shows a macronucleus and a normal nucleus that stands close to the germ tube. $\mathrm{Bar}=10 \mu \mathrm{m}$.

Table I - Comparisons between nuclei of conidia and macronuclei of hülle cells.

\begin{tabular}{lccc}
\hline & $\begin{array}{c}\text { Nucleus } \\
(\text { conidium })\end{array}$ & $\begin{array}{c}\text { Macronucleus } \\
\text { (hülle cell) }\end{array}$ & $\begin{array}{c}\text { Ratio } \\
\text { macronucleus / nucleus }\end{array}$ \\
\hline Diameter $(\mu \mathrm{m})$ & $1.1 \pm 0.19^{*}$ & $3.1 \pm 0.43^{* *}$ & 2.7 \\
Volume $\left(\mu \mathrm{m}^{3}\right)$ & 0.69 & 14.13 & 20.5 \\
$\begin{array}{l}\text { DNA }\left(\mu \mathrm{g} / 10^{8}\right. \\
\text { cells })\end{array}$ & 2.0 & 34.4 & 17.2 \\
& $\begin{array}{c}\text { Mean } \pm \mathrm{SD} \\
(\mathrm{n}=50)\end{array}$ & $\begin{array}{c}* * \text { Mean } \pm \mathrm{SD} \\
(\mathrm{n}=25)\end{array}$ \\
\hline
\end{tabular}

is possible that in the process of germination the macronucleus disintegrates and the germ tube is formed from a normal nucleus.
Comparisons between nuclei of conidia and macronuclei of hülle cells are presented in Table I. By comparing the volume of nuclei with that of macronuclei, the latter were found to have a volume 20.5 times higher than that estimated for nuclei. And as expected, the amount of DNA found in hülle cells was 17.2 times higher than that found in the conidia.

Although a special strain has been analyzed in detail, macronuclei were also observed in mature hülle cell of $\mathrm{A}$ and biA1;meth $\mathrm{G} 1$ strains, that seems to indicate that the formation of macronuclei is a characteristic of any hülle cell of A.nidulans

\section{References}

Doby JM and Kombila-Favray M (1978) Presence de formes sexuées ( cleistotheces et hulle-cells), dans un cas humain d'aspergillose du sinus maxillaire chez Aspergillus nidulans associé a Aspergillus fumigatus. Mycopathologia 64(3):157-163.

Eidam E (1883) Zur Kenntniss der Entwicklung bei den Ascomyceten. III Sterigmatocystis nidulans n. sp. In: FS Cohn, Beitr Biol Pflanzen 3:392-441.

Ellis TT, Reynolds DR and Alexopoulos CJ (1973) Hülle cells development in Emericella nidulans. Mycologia 65:10291035.

Giles KW and Myers A (1965) An improved diphenylamine method for the estimation of deoxyribonucleic acid. Nature 206:93.

Herman TE, Kurtz MB and Champ SP (1983) Laccase localized in hülle cells and cleistothecial primordia of Aspergillus nidulans. Journal of Bacteriology 154:955-964.

Nga BH and Roper JA (1968) Quantitative intrachromosomal changes arising at mitosis in Aspergillus nidulans. Genetics 58:193-209.

Pontecorvo G, Roper JA, Hemmons DW, Macdonald KD and Bufton AW (1953) The genetics of Aspergillus nidulans. Advances in Genetics 5:141-238.

Raper KB and Fennell DI (1973) The genus Aspergillus. Hutington, New York. R.E. Krieger Publishing Company, $686 \mathrm{pp}$.

Roper JA (1958) Production of heterozygous diploids in filamentous fungi. Experientia 8:14-15.

Schwatz W (1928) Entwichlungsphysiologische Untersuchungen uber die Gattungen Aspergillus und Penicillium I. Aspergillus-Artem Flora (Jena) 23:386-440.

Tuyl JM van (1977) Genetics of fungal resistance to systemic fungicides. Mededelingen Landbowhogeschool Wageningen, Nederland, $136 \mathrm{pp}$.

Zonneveld BJM (1988) Morphology of initials and number of nuclei initiating cleisthothecia in Aspergillus nidulans. Transactions of the British. Mycological Society 90:369-373. 